\title{
Hedge Accounting in the Brazilian Stock Market: Effects on the Quality of Accounting Information, Disclosure, and Information Asymmetry ${ }^{*}$
}

\author{
Silas Adolfo Potin \\ Universidade Federal do Espírito Santo, Centro de Ciências jurídicas e Econômicaș, Departamento de Ciências Contábeis, Vitória, ES, Bràzil
}

Patrícia Maria Bortolon

Universidade Federal do Espírito Santo, Centro de Ciências Jurídicas e Econômicas, Departamento de Ciências Contábeis, Vitória, ES, Brazil

Alfredo Sarlo Neto

Universidade Federal do Espírito Santo, Centro de Ciências Jurídicas e Econômicas, Departamento de Ciências Contábeis, Vitória, ES, Brazil

Received on 08.24.2015 - Desk acceptance on 09.11.2015 - $2^{\text {nd }}$ version approved on 03.01.2016.

\begin{abstract}
This paper investigates, in the Brazilian stock market, the effect of hedge accounting on the quality of financial information, on the disclosure of derivative financial instruments, and on the information asymmetry. To measure the quality of accounting information, relevance metrics of accounting information and book earnings informativeness were used. For executing this research, a general sample was obtained through Brazilian companies, non-financial, listed on the Brazilian Securities, Commodities, and Futures Exchange (BM\&FBOVESPA), comprising the 150 companies with highest market value on 01/01/2014. Through the general sample, samples were compiled for applying the econometric models of value relevance, informativeness, disclosure, and information asymmetry. The sample for relevance had 758 companies-years observations within the period from 2008 to 2013; the sample for informativeness had 701 companies-years observations.with the period from 2008 to 2013; the sample for disclosure had 100 companies-years observations, within the period from 2011 to 2012; the sample for information asymmetry had 100 companies-years observations, also related to the period from 2011 to 2012. In addition to the econometric models, the propensity score matching method was applied to the analyses of the hedge accounting effect on disclosure and information asymmetry. The evidence found for the influence of hedge accounting indicates a relation: (i) positive and significant concerning accounting information relevance and disclosure of derivatives; (ii) negative and significant for book earnings informativeness. Regarding information asymmetry, although the coefficients showed up as expected, they were not statistically significant.
\end{abstract}

Keywords: hedge accounting, relevance, informativeness, disclosure, information asymmetry. 


\section{INTRODUCTION}

In Brazil, according to the movement to harmonize with the international accounting standards, the Brazilian Accounting Pronouncements Committee (CPC) issued, in the end of 2008, the CPC 14, subsequently replaced by the CPCs 38,39 , and 40 , which deal with financial instruments. In addition to regulate accounting for such instruments, making them balance sheet items, the accounting standards mentioned above establish conditions so that corporations can qualify for hedge accounting (HA). However, these standards are not mandatory and provide entities with the possibility of adopting this methodology.

For qualifying to HA, a company should formally designate the relationship between the hedged object and the hedging instrument, as well as complying with many other criteria set by the standard. However, when a company hires a hedge derivative and it does not designate the HA, the outcome of variation in the fair value of this derivative directly impacts the company's outcome in the period. The volatility derived from variation in the fair value of derivatives may incur in an excessive volatility with regard to the accounting outcome, which could not adequately reflect the underlying economic fundamentals and, as a consequence, distort managers' decision (Plantin, Sapra, \& Shin, 2008; Chen, Tan, \& Wang, 2013).

The incentive for companies to take HA consists in the possibility to compare the outcome of the hedging instrument to the result of the hedged object, by respecting the principle of competence (Pirchegger, 2006). Thus, HA was created to be a benefit to businesses, by avoiding increased volatility of earnings associated with fair value accounting (Hughen, 2010).

According to the theoretical model developed by DeMarzo and Duffie (1995) and supported by empirical evidence provided by Dadalt, Gay and Nam (2002), hedging activities and, as a consequence, HA contribute to reduce information asymmetry and agency costs. Thus, companies that use hedge tend to decrease agency costs, allowing the market to assign prices closer to values inherent to its stocks, reducing the mispricing of shares and increasing both the predictability of cash flows and earnings, as well as analysts' accuracy (Lin, Pantzalis, \& Park, 2010; Panaretou, Shackleton, \& Taylor, 2013).

DeMarzo and Duffie (1995) also highlight the informational effect of hedge. According to the authors, the information arising from $\mathrm{HA}$ is relevant, because it provides the market with information on the origin and magnitude of the risks underlying the company. The authors also stipulate that the hedge increases earnings informativeness, as they become components to assess management capability. Earnings informativeness is de- fined as the association between share price and accounting information disclosed, as measured by the slope coefficient that relates earnings and stock price return (Francis, Olsson, \& Schipper, 2006).

In Brazil, recent cases showing potential outcomes of adopting HA arouse the market's attention to this type of mechanism. In the second 2013 quarterly report, PETROBRAS announced the adoption of HA for its exports. Adherence to this methodology allowed the withdrawal of $\mathrm{R} \$ 7.98$ billion in financial losses from the outcome, reversing a loss of $\mathrm{R} \$ 1.3$ billion and registering a $\mathrm{R} \$ 6.2$ billion profit (Viri, 2013).

Thus, we notice that the HA has an outstanding relevance both for the market and the academy. Considering this, in order to increase understanding on the usefulness of accounting information for the Brazilian market, this study aims to investigate the effect of hedge accounting in the quality of financial information disclosed by non-financial companies listed on the Brazilian Securities, Commodities, and Futures Exchange (BM\&FBOVESPA) and check its influence on the disclosure level and information asymmetry.

Since in the current literature there is no consensus metrics for measuring the quality of accounting information, many researchers made use of models that capture various accounting properties, such as: relevance, outcomes management, conservatism, earnings informativeness, and timing (Wang, 2006; Lopes, 2009; Almeida, 2010). In this research, the quality of accounting information will be measured by the accounting information relevance and book earnings informativeness.

Thus, to achieve the research goal, hypotheses were developed having the reviewed theory as a basis, which relate aspects of accounting information and HA, namely:

$\mathrm{H}_{1}$ - HA has a positive influence on the accounting information relevance;

$\mathrm{H}_{2}$ - HA has a positive influence on book earnings informativeness;

$\mathrm{H}_{3}$ - HA is positively related to a higher level of disclosure of derivative financial instruments;

$\mathrm{H}_{4}-\mathrm{HA}$ is negatively related to information asymmetry.

This article seeks to contribute to the existing literature by increasing knowledge on the application of HA by Brazilian companies traded on the BM\&FBOVESPA, a theme which remains largely unexplored by the studies carried out in Brazil. In this way, the work conducted herein shows evidence that contribute to grasp the influence of HA on the quality of accounting information, disclosure of derivatives, and information asymmetry in the Brazilian market. 


\section{THEORETICAL FRAMEWORK}

\subsection{Derivative Financial Instruments and Hedge Accounting}

According to Amaral (2003), derivatives are financial instruments derived from other assets or contracts negotiated between the parties and traded on a secondary market, and the most common types are forward contracts, futures contracts, purchase (call) and sale (put) options, and swap contracts. The author also points out that these instruments allow the transfer of risks, market or credit risk, between those who seek protection (hedgers) and speculators.

According to the CPC 38 (2009), derivatives are financial instruments or other contracts that take three characteristics, namely: (i) value changes due to certain variables (interest rate, exchange rate, prices, commodities, among others); (ii) there is no need for an initial net investment or an investment lower than that required for other types of contract; and (iii) it is settled at a future date.

Darós and Borba (2005) highlight that the derivative financial instruments have become a significant strategic component of corporate risk management. Given the risks arising from price fluctuations, interest rates, exchange rate variations, or also other variations that affect the value of assets or future cash flow, companies use derivatives as a protection means (hedge) in relation to these risks (Lopes, Galdi, \& Lima, 2009).

In the literature, the use of derivatives and corporate hedging activities has been investigated from various perspectives. Many of these studies are based on the relaxation of the proposition I by Modigliani and Miller (1958) and seek to correlate the hedging activities to the firm value. According to the paradigm by Modigliani and Miller (1958), considering a perfect, frictionless, market, corporate hedging activities might be irrelevant, since the shareholders would reduce risks by diversifying their portfolios.

However, Stulz (1984) highlights that, in a more realistic scenario, with the presence of market frictions, although external shareholders can diversify their portfolios, managers cannot do the same. Thus, the author points out that the company hedging activity is a consequence of risk aversion on the part of managers.

From the perspective of internal users of accounting information, in an empirical study, Chen et al. (2013) provide evidence that, despite substantial economic benefits, many managers eschew hedging certain risks due to concerns about the accounting impact of fair value. According to the authors, this effect is magnified when the volatility of the hedged object price is higher, when the hedging activity might be paradoxically justified.

HA, whose adoption is allowed to companies by the accounting standards, aims to apply the competence basis to the gain and loss of variations at fair value of hedging instruments and the hedged object, so that these variations are simultaneously recognized in the fiscal year outcome (Pirchegger, 2006). Thus, this methodology aims to reflect the economic substance of the transaction, in order to solve the issue of comparing the existing results concerning the use of derivatives (Lopes et al., 2009).

In Brazil, in a recent paper, Silva (2014) investigated the relation between the adoption of HA and the cost of equity in Brazilian listed companies, in addition to administration incentives to adopt HA. The findings of this author indicate: (i) strong evidence that the adoption of HA resulted in decreased volatility of accounting outcomes; (ii) strong negative association between the cost of equity and financial instruments designated for HA; and (iii) positive probability ratio of adopting HA with funding abroad, return on assets, revenue in foreign currency, company size, investments abroad, indebtedness level, and with companies issuing American depositary receipts (ADRs) or a financial institution.

\subsection{Quality of Accounting Information}

In the end of the 1960s, the seminal papers by Ball and Brown (1968) and Beaver (1968) mark the beginning of a new perspective and a new field of study in accounting research, known as information approach. According to Lopes (2002, p. 20), "the information approach thinks of accounting in its role as provider of information for economic agents." Thus, a number of accounting studies were conducted by using capital market responses to reported earnings to infer the quality of accounting information (Dechow, Ge, \& Schrand, 2010). These studies are structured according to the positive theory of accounting approach, where statistical models seek to measure, through the information approach, the association between accounting and market variables (Watts \& Zimmerman, 1986).

Almeida (2010) highlights that many users of accounting information have different specific demands. However, meeting every demand might entail a high cost for preparing and disclosing such information. Thus, the agencies responsible for issuing pronouncements - such as the CPC - recommend that the accounting information produced and disseminated meet the largest number of general users possible.

As already mentioned, in the current literature there is no consensus metrics for measuring the quality of accounting information. Thus, many researchers resorted to models that capture various accounting properties, such as: relevance, results management, conservatism, earnings informativeness, and timing (Wang, 2006; Lopes, 2009; Almeida, 2010).

In this study, the quality of accounting information will be analyzed from the perspective of accounting information relevance and earnings informativeness.

\subsubsection{Accounting information relevance.}

A piece of accounting information becomes relevant when it changes user's decision (Francis et al., 2006). Barth, Beaver and Landsman (2001) emphasize that only relevant and reliable information may be used for decision making and to influence market values. From the accounting and informational viewpoint, information relevance consists in 
the predictability of future cash flows (Lopes \& Martins, 2012). By using market reaction to measure the influence of accounting statements to aid its users to predict companies' future cash flows, accounting information relevance is closely related to the concept of quality of earnings (Scott, 2011).

Since accounting information relevance consists in the predictability of future outcomes (Lopes \& Martins, 2012), Panaretou et al. (2013) show the accounting information relevance present in HA. Measuring the error dispersion of analysts' forecasts for companies' earnings, the authors argue that HA influences the predictability of companies' outcomes, making them more predictable in companies that adopted HA. Also according to the authors, information coming from HA provide market analysts with greater accuracy in their analysis and forecasts.

\subsubsection{Book earnings informativeness.}

In an efficient market scenario, share prices vary in relation to the expectations of generating cash flow and future earnings (Francis et al., 2006). Thus, considering an efficient market, stock returns should vary with the same intensity and direction than book earnings (Beaver, Clarke, \& Wright, 1979).

Although the impact of disclosing book earnings on the book share prices has been identified by several studies, their results did not show a perfect correlation, i.e. though varying in the same direction, share prices and profits do not vary on the same scale (Sarlo Neto, Galdi, \& Dalmácio, 2009). Several studies have analyzed various variables that influence this relation; among them, we may mention Freeman (1987), Collins and Kothari (1989), Dhaliwal, Lee and Fargher (1991), and Vafeas (2000), which showed the relation between earnings and firm size, growth opportunity, leverage, and the structure of the board of directors.

The hedge information content is addressed by DeMarzo and Duffie (1995), who highlight that adopting hedge policies increases earnings informativeness and this happens to be used by shareholders as a way to measure management ability, as well as the quality of investment concerning coverage of risks.

\subsection{Information Asymmetry and Hedge Accounting}

The Agency Theory, according to Jensen and Meckling (1976), predicts that managers do not always act towards the best interest of shareholders. In markets having a concentrated ownership structure, the most prominent agency conflict takes place in the relation between controlling shareholders and non-controlling shareholders (La Porta, Lopez-de-Silanes, Shleifer, \& Vishny, 2000).

Accounting is a mechanism that allows assessing management performance and capacity, contributing to reduce information asymmetry (Bushman \& Smith, 2001; Healy \& Palepu, 2001).

Considering the information asymmetry between shareholders and managers, above all concerning the origin and magnitude of risks that companies face, DeMarzo and Duffie (1995) highlight that companies practice hedging based on private information that cannot be provided to shareholders free of any aggregate cost. The authors also stress that, when a hedging activity takes place and hedge positions are disclosed, risks that may interfere with company's earnings become better known, above all regarding company's exposure, decreasing information asymmetry about company's outcomes.

\section{METHODOLOGY}

\subsection{Samples}

The population consists in the companies traded on the BM\&FBOVESPA. To constitute the sample, the population was arranged in descending size order, on the base date December 30, 2013. Thereafter, the identifica- tion process of adopting or not HA began; it was found that, after the $150^{\text {th }}$ company, the incidence of adopting HA decreased considerably, a factor that determined the selection threshold. Table 1 illustrates the selection procedures of each sample.

Table 1 Constitution of the final samples for quality of accounting information

\begin{tabular}{ll}
\hline Panel A - Constitution of the sample for relevance & \\
\hline General sample for quality of accounting information & 900 \\
(-) Exclusion of firm-year observations due to absence of value (miss value) in the database & $(12)$ \\
(-) Exclusion due to processing of outliers & \\
(=) General sample for relevance & 758 \\
\hline Panel B - Constitution of the sample for informativeness & \\
\hline General sample for quality of accounting information & (172) \\
(-) Exclusion of firm-year observations due to absence of value (miss value) in the database \\
(-) Exclusion due to processing of outliers \\
(=) General sample for informativeness
\end{tabular}


Considering the findings by Silva (2014), which indicate that the probability of adopting $\mathrm{HA}$ is positively associated with obtaining resources abroad, revenues in foreign currency, company size, among others, the samples highlighted in Panels A and B of Table 1 may fail to provide an analysis of the effects of HA on the quality of accounting information, but they provide information on the accounting complexity inherent to large companies. Thus, samples of comparable companies were created, searching, for each firm-year observation of a company that adopted HA, its counterfactual, i.e. a firm-year observation of a company that did not adopt HA and had a similar size measured by total assets. Thus, the comparable sample for relevance had 350 firm-year observations, 175 with HA and 175 without HA; the comparable sample for informativeness had 326 firm-year observations, 163 with HA and 163 without HA.

The sample for analyzing the effect of HA on the disclosure level of derivatives consisted of the 50 largest companies that operated with derivative financial instru- ments in the fiscal years 2011 and 2012, totaling 100 firms-years. Limiting to the top 50 is justified by the extensive manual collection and the need that they operated with derivatives in the two years observed. The sample resorted to 48 firm-year observations regarding the use of HA and 62 firm-year observations without HA.

The sample used to investigate the effects of HA on information asymmetry was based on the same $50 \mathrm{com}$ panies analyzed in the sample for disclosure. Thus, the companies not followed up by market analysts were excluded, or those accompanied by only one analyst. Thus, the sample consisted in 66 observations of 33 companies.

\subsection{Relevance Model Description}

The value relevance model aims to analyze change in the expectation of economic agents, regarding future outcomes, through the information content of reported book figures (Barth et al., 2001; Lopes \& Martins, 2012).

The model for relevance used in this research consists in adapting the model proposed by Ohlson (1995):

$$
A M V_{i, t}=\beta_{0}+\beta_{1} A E Q_{i, t}+\beta_{2} A N E_{i, t}+\varepsilon_{i, t}
$$

Where:

$A M V_{i, t}$ is the market value of company $i$ in year $t$, adjusted to market value in $\mathrm{t}-1$;

$A E Q_{i, t}$ is the equity of company $i$ in year $t$, adjusted to market value in $\mathrm{t}-1$;
$A N E_{i, t}$ is the net earnings of company $i$ in year $t$, adjusted to market value in $\mathrm{t}-1$.

Thus, we added the variable that reflects the use of HA, the variables of interaction and the variables of control, as represented by the equation:

$$
A M V_{i, t}=\beta_{0}+\beta_{1} A E Q_{i, t}+\beta_{2} A N E_{i, t}+\beta_{3} D H A_{i, t}+\beta_{4} A E Q_{i, t} * D H A_{i, t}+\beta_{5} A N E_{i, t} * D H A_{i, t}+\sum_{1}^{n} \gamma_{n} \operatorname{Control}_{i, t}+\varepsilon_{i, t}
$$

Where:

$A M V_{i, t}$ is the market value of company $i$ in year $t$, adjusted to market value in $\mathrm{t}-1$;

$A E Q_{i, t}$ is the equity of company $i$ in year $t$, adjusted to market value in $\mathrm{t}-1$;

$A N E_{i, t}$ is the net earnings of company $i$ in year $t$, adjusted to market value in $\mathrm{t}-1$;

$D H A_{i, t}$ is the dummy variable that takes value 1 when company $i$ used HA in year $t$, otherwise, it takes value 0 ;

Control $_{i, t}$ are the control variables of company $i$ in year $t$, and this model controls size, growth opportunity, and leverage.
For the model for relevance, it is expected that the coefficients of interest, $\beta_{3}, \beta_{4}$, and $\beta_{5}$, are positive and significant.

\subsection{Informativeness Model Description}

The informativeness model is usually specified in an equation where return on share is taken as dependent variable and net income as an explanatory variable (Easton \& Harris, 1991). This model seeks to measure market reaction in face of book earnings disclosure.

The informativeness model used in this research is adapted from Easton and Harris (1991): 


$$
R_{i, t}=\beta_{0}+\beta_{1} \cdot N E_{i, t}+\varepsilon_{i, t}
$$

Where:

$R_{i, t}$ is the return on share of company $i$ in period $t$; $N E_{i, t}$ is the net earnings of company $i$ in period $t$.

In accordance with the procedures performed by Sarlo Neto, Lopes and Dalmácio (2010), Sarlo Neto, Bassi and Almeida (2011), Brugni, Sarlo Neto, Bastia- nello and Paris (2012), Yokoyama, Baioco, Rodrigues Sobrinho and Sarlo Neto (2015), the original model by Easton and Harris (1991) added the variable that reflects the use of $\mathrm{HA}$, the variable of interaction and the variables of control, as represented by the equation:

$$
R S_{i, t}=\beta_{0}+\beta_{1} A N E_{i, t}+\beta_{2} D H A_{i, t}+\beta_{3} A N E_{i, t}^{*} D H A_{i, t}+\sum_{1}^{n} \gamma_{n} \text { Control }_{i, t}+\varepsilon_{i, t}
$$

Where:

$R S_{i, t}$ is the excessive return on share of company $i$ in year $t$ in relation to the IBOVESPA;

$A N E_{i, t}$ is the net earnings of company $i$ in year $t$, adjusted to market value in $\mathrm{t}-1$;

$D H A_{i, t}$ is the dummy variable that takes value 1 when company $i$ used HA in year $t$, otherwise, it takes value 0 .

Control $_{i, t}$ are the control variables of company $i$ in year $t$, and this model controls size, growth opportunity, and leverage.

It is expected that $\beta_{3}$ is positive and significant, something which shows that HA has a positive influence on book earnings informativeness.

\subsection{Disclosure Model Description}

Considering the use of derivatives and HA, scholars empirically investigated whether HA reduces information asymmetry. The disclosure level of derivatives was evaluated by the DDI (described in item 3.6), which is taken as the dependent variable. The control variables were added with size, leverage, stock market liquidity, corporate governance, and ADR, based on variables that the literature identifies as critical to the disclosure level (Lanzana, 2004; Alencar, 2005; Murcia \& Santos, 2009).

Determinants of the disclosure level were evaluated, according to the following model:

$$
D D I_{i, t}=\beta_{0}+\beta_{1} S I Z E_{i, t}+\beta_{2} L E V_{i, t}+\beta_{3} L I Q_{i, t}+\beta_{4} D G O V_{i, t}+\beta_{5} D A D R_{i, t}+\beta_{6} D H A_{i, t}+\varepsilon_{i, t}
$$

Where:

$D D I_{i, t}$ is the derivatives disclosure indicator of company $i$ in year $t$;

$S I Z E_{i, t}$ is the proxy for company size $i$ in year $t$;

$L E V_{i, t}$ is the leverage of company $i$ in year $t$;

$L I Q_{i, t}$ is the stock market liquidity of company $i$ in year $t$;

$D G O V_{i, t}$ is the dummy variable that takes value 1 for companies adhering to one of the different listing segments of the BM\&FBOVESPA, i.e. segments Level 1, Level 2, or New Market;

$D A D R_{i, t}$ is the dummy variable that takes value 1 if company $i$ traded ADRs year $t$, otherwise, it takes value 0 ;

$D H A_{i, t}$ is the dummy variable that takes value 1 when company i used HA in year $t$, otherwise, it takes value 0 .

It is expected that $\beta_{6}$ is positive and significant. If this comes true, it will evidence that HA has a positive influence on the disclosure level of derivatives.

\subsection{Information Asymmetry Model Description}

If the expected $\beta_{6}$ coefficient for the disclosure model (M5) is confirmed, the equation M6 will be used to test whether HA reduces information asymmetry concerning the use of derivatives. In this model, the dispersion variable of analysts' forecasts $\left(\mathrm{DAFA}_{\mathrm{i}, \mathrm{t}}\right)$ is taken as a proxy for information asymmetry, in a procedure similar to that in Dadalt et al. (2002). Thus, DAFA ${ }_{i, t}$ is regressed against $\mathrm{DDI}_{\mathrm{i}, \mathrm{t}}$ and the other control variables, according to the equation:

$$
D A F A_{i, t}=\beta_{0}+\beta_{1} D D I_{i, t}+\sum_{1}^{n} \gamma_{n} \text { Control }_{i, t}+\varepsilon_{i, t}
$$

Where:

$D A F A_{i, t}$ is the dispersion of the average forecast of analysts following company $i$ in year $t$;

$D D I_{i, t}$ is the derivatives disclosure indicator of company $i$ in year $t$

Control are the control variables of company $i$ in year $t$. In this model, it is expected that $\beta_{1}$ is negative and significant. 


\subsection{Construction of the Derivatives Disclosure Indicator}

To measure the disclosure level of derivative financial instruments, the "Derivatives Disclosure Indicator" (DDI) was constructed, consisting of issues prepared by having the CPC 40 (R1) as a basis, assigning 1 for compliance with the standard and 0 for non-compliance with it. The list of issues in the DDI is provided in Table 2 .

Table 2 Metrics for a derivatives disclosure index

\begin{tabular}{|c|c|c|}
\hline Indicator & Name & Regulation CPC 40(R1) \\
\hline 1 & Book value of each category. & Item 8, paragraphs "a" to "f." \\
\hline 2 & Value of variation at fair value. & Items 9 and 10. \\
\hline 3 & Exposure to risk. & Item 33, paragraph “a." \\
\hline 4 & Objectives, policies, and processes. & Item 33, paragraph "b." \\
\hline 5 & Risk measurement method. & Item 33, paragraph "b." \\
\hline 7 & The company should disclose the analysis of sensitivity to risks. & Items 40 and 41. \\
\hline 8 & $\begin{array}{l}\text { Unfolding of outcomes and equity in the possible scenarios of changes } \\
\text { in relevant risks. }\end{array}$ & Items 40 and 41. \\
\hline 9 & Methods and assumptions of the analysis. & Items 40 and 41. \\
\hline 10 & Net outcome from operations with derivatives. & Item 20. \\
\hline 12 & Counterpart. & Item 34, paragraph "c" and B8. \\
\hline
\end{tabular}

Source: Prepared by the author.

\subsection{Propensity Score Matching}

In addition to the study to investigate the influence of HA on disclosure and information asymmetry, through regressions, as highlighted in sections 3.4 and 3.5, this research will also resort to the propensity score matching technique, known as PSM, in order to investigate the causal effect of HA on disclosure and information asymmetry.

Propensity score is the conditional probability of exposure to some treatment, given a vector of observed covariables (Rosenbaum \& Rubin, 1983). To identify the causal effect, however, a problem may be caused. The outcome variable to analyze the causal effect - for this research we have DDI and DAFA - it is observed, in a year $\mathrm{i}$, by one or another case where the company has or does not have HA, but it is never seen in both cases for the same company in a given year $i$. It is understood that, according to the counterfactual theory of causation, the ideal might be to analyze the same company in similar contexts, but differing only in the treatment circumstance, in this case having HA or not.

Considering the impossibility of this format, the causal effect is estimated by the average treatment effect when comparing a set of observations with statistically identical observable features, distinguished by treatment, wherein a series comprises the treatment group and the other does not, in a sample where companies are randomly assigned to treatment.

A solution to the problem described above is using the Propensity Score Theorem, proposed by Rosenbaum and Rubin (1983). Through this theorem, the correspondence between companies is obtained by means of a propensity score, derived from a function of all the observable features that could potentially affect the adoption of HA by a company; the propensity score may be obtained by affinity models (logit or probit).

\section{DATA ANALYSIS AND RESEARCH RESULTS}

\subsection{Analysis of Relevance and Informativeness}

To estimate the effects of HA on the relevance of information, we used the multiple regression technique with panel data and fixed effects approach, following the models M1 and M2 for the sample for relevance, as well as the regression of model M2 for the sample with comparable elements for relevance. The results are shown in Table 3.

Table 3 Results of regressions in the relevance model

\begin{tabular}{cccc}
\hline & $\begin{array}{c}\text { General sample } \\
\text { for relevance }\end{array}$ & $\begin{array}{c}\text { General sample } \\
\text { for relevance }\end{array}$ & $\begin{array}{c}\text { Sample with comparable } \\
\text { elements for relevance }\end{array}$ \\
\hline \multirow{2}{*}{ Variables } & M1 - Original model & M2 - Adapted model & M2 - Adapted model \\
\cline { 2 - 4 } & $\begin{array}{c}\text { Coefficient } \\
\text { (Robust standard error) }\end{array}$ & $\begin{array}{c}\text { Coefficient } \\
\text { (Robust standard error) }\end{array}$ & $\begin{array}{c}\text { Coefficient } \\
\text { (Robust standard error) }\end{array}$ \\
\hline $\mathrm{AEQ}_{\mathrm{i}, \mathrm{t}}$ & $\mathbf{1 . 4 8 6}^{* * *}$ & $\mathbf{1 . 6 2 6}^{* * *}$ & $\mathbf{1 . 3 1 6 ^ { * * * }}$ \\
\hline
\end{tabular}


Table 3

Cont.

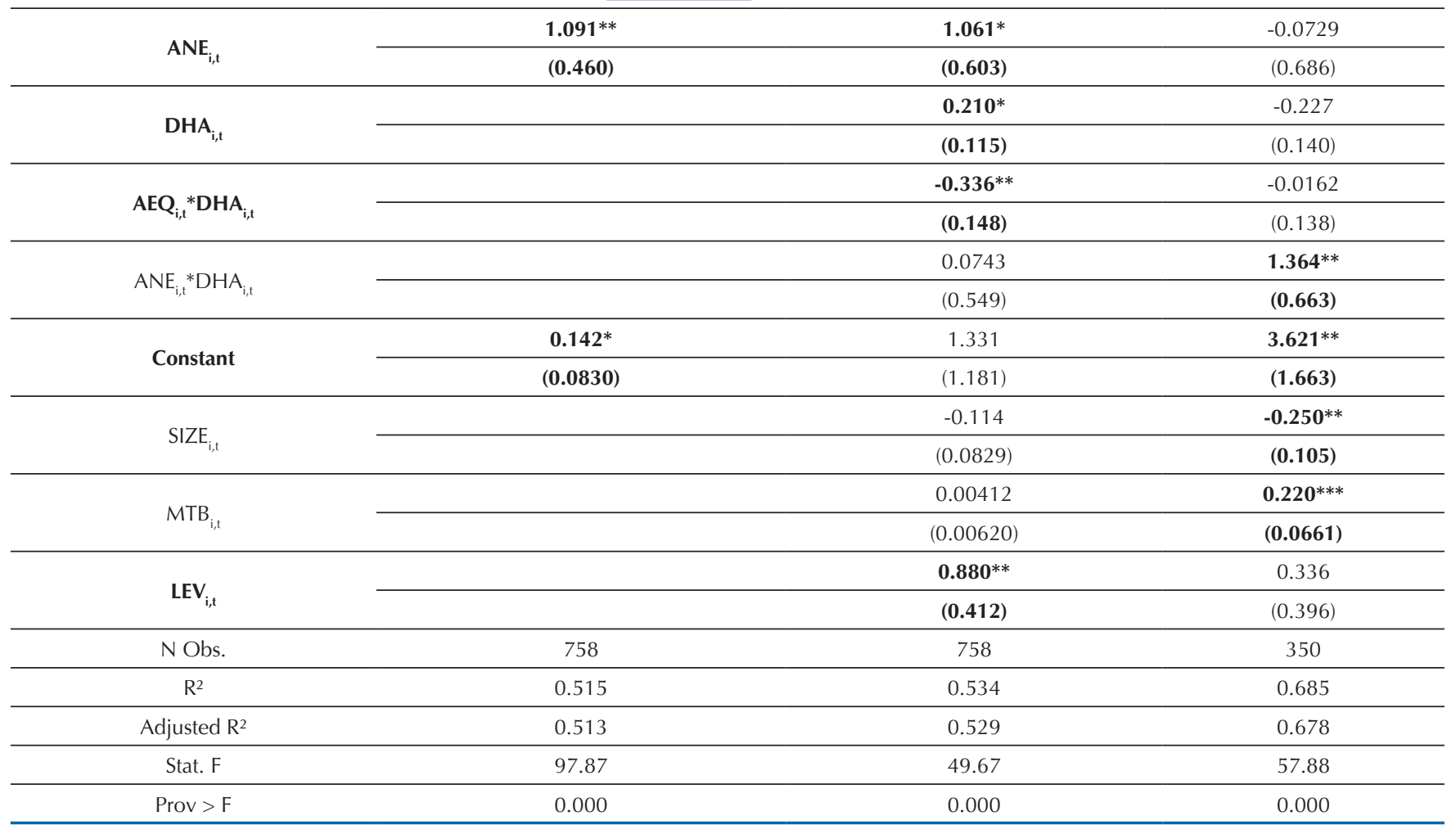

Note. $A M V_{i t}$ - market value of company $i$ in year $t$, adjusted to market value in $\mathrm{t}-1 ; A E Q_{i t}$ - equity of company $i$ in year $t$, adjusted to market value in $\mathrm{t}-1$; $A N E_{i t}-$ net earnings of company $i$ in year $t$, adjusted to market value in $\mathrm{t}-1 ; D H A_{i, t}-$ dummy variable that takes value 1 when company $i$ used $\mathrm{HA}$ in year $t$, otherwise, it takes value 0; $A E Q_{i, t}{ }^{*} D H A_{i t}$ - interaction between the dummy of $\mathrm{HA}$ and AEQ; $A N E_{i, t}{ }^{*} D H A_{i t}$ - interaction between the dummy of HA and ANE; SIZE. - proxy for size of company $i$ in year $t, M T B_{i, t}$ - proxy for growth opportunity of company $i$ in year $t ; L E V_{i, t}$ - proxy for leverage of company $i$ in year $t$; ${ }^{* * *}, * * *$, significant at $1 \%$, $5 \%$, and $10 \%$, respectively.

Source: Prepared by the author.

According to Table 3, when analyzing the sample for relevance, it is observed that the slope coefficient of interaction between ANE and DHA is positive, but not significant. In turn, the interaction between AEQ and DHA is significant at $5 \%$ and it has a negative slope. This denotes that HA has a negative effect on the relevance of equity. This result is contrary to what is expected and highlighted by the theoretical framework. This evidence also refers to the issue that the results for this sample may be picking up several other factors, such as the complexity of accounting inherent to large companies.

In this occasion, there was an analysis of a sample with comparable observations, looking for each firm-year observation of a company that adopted HA its counterfactual, i.e. a firm-year observation of a company that did not adopt HA and had a similar size measured by total assets. For the aforementioned results, it is observed that the slope coefficient of the interaction between AEQ and DHA is negative, but not significant. In turn, the interaction between ANE and DHA is significant at $5 \%$ and it has a positive slope. Corroborating the reviewed theory, this evidence converges to the understanding that HA has a positive effect on the relevance of net earnings. Thus, HA, by enable the comparison by competence of the hedging instrument to the hedged object in the company outcome, allows the market to recognize information in the disclosed outcomes of companies.

Based on the results obtained from the relevance model, for the comparable sample for relevance, aligned to the expected results, $\mathrm{H}_{1}$ is not rejected.

Table 4 displays the results of regressions of the original model (M3) and the informativeness model used in this research (M4) for the sample for informativeness, and regression of the model M4 for the sample with comparable elements for informativeness.

Table 4 Results of regressions of the informativeness model

\begin{tabular}{cccc}
\hline & $\begin{array}{c}\text { General sample } \\
\text { for informativeness }\end{array}$ & $\begin{array}{c}\text { General sample } \\
\text { for informativeness }\end{array}$ & $\begin{array}{c}\text { Sample with comparable ele- } \\
\text { ments for informativeness }\end{array}$ \\
\hline Variables & M3 - Original model & M4 - Adapted model & M4 - Adapted model \\
\cline { 2 - 4 } & $\begin{array}{c}\text { Coefficient } \\
\text { (Robust standard error) }\end{array}$ & $\begin{array}{c}\text { Coefficient } \\
\text { (Robust standard error) }\end{array}$ & $\begin{array}{c}\text { Coefficient } \\
\text { (Robust standard error) }\end{array}$ \\
\hline ANE $_{\mathrm{i}, \mathrm{t}}$ & $\mathbf{1 . 5 0 8 ^ { * * * }}$ & $\mathbf{1 . 7 2 4}^{* * *}$ & $\mathbf{2 . 0 4 0 ^ { * * * }}$ \\
\hline
\end{tabular}


Tabela $4 \quad$ Resultados das regressões do modelo de informatividade

\begin{tabular}{|c|c|c|c|}
\hline \multirow{2}{*}{$\mathrm{DHA}_{\mathrm{i}, \mathrm{t}}$} & & 0.0898 $^{* *}$ & $0.0874^{*}$ \\
\hline & & $(0.0421)$ & $(0.0462)$ \\
\hline \multirow{2}{*}{$\mathrm{ANE}_{\mathrm{i}, \mathrm{t}}{ }^{*} \mathrm{DHA}_{\mathrm{i}, \mathrm{t}}$} & & $-0.866^{* *}$ & $-1.148^{* *}$ \\
\hline & & $(0.417)$ & $(0.482)$ \\
\hline \multirow{2}{*}{ Constant } & 0.00605 & 0.252 & $0.424 * *$ \\
\hline & $(0.0207)$ & $(0.161)$ & $(0.203)$ \\
\hline \multirow{2}{*}{$\operatorname{SIZE}_{\mathrm{i}, \mathrm{t}}$} & & -0.0138 & $-0.0259 * *$ \\
\hline & & (0.0106) & $(0.0120)$ \\
\hline \multirow{2}{*}{ MTB $_{i, t}$} & & $0.0167^{* * *}$ & $0.0169 * * *$ \\
\hline & & $(0.00474)$ & $(0.00521)$ \\
\hline \multirow{2}{*}{ LEV $_{\mathrm{i}, \mathrm{t}}$} & & $-0.197 * * *$ & -0.149 \\
\hline & & $(0.0750)$ & $(0.101)$ \\
\hline N Obs. & 701 & 701 & 326 \\
\hline $\mathrm{R}^{2}$ & 0.102 & 0.169 & 0.202 \\
\hline Adjusted R² & 0.101 & 0.162 & 0.187 \\
\hline Stat. F & 55.14 & 14.65 & 10.51 \\
\hline Prob $>F$ & 0.000 & 0.000 & 0.000 \\
\hline
\end{tabular}

Note. $R S_{i, t}$ - excessive return of company $i$ in year $t$ in relation to the IBOVESPA; $A N E_{i, t}$ net earnings of company $i$ in year $t$, adjusted to market value in t-1; $D H A_{i, t}$ - dummy variable that takes value 1 when company $i$ used $\mathrm{HA}$ in year $t$, otherwise, it takes value $0 ; A N E_{i, t}{ }^{*} D H A_{i, t}$ interaction between the dummy of HA and ANP; $S I Z E_{i, t}$ - proxy for the size of company $i$ in year $t, M T B_{i, t}$ - proxy for the growth opportunity of company $i$ in year $t, L E V_{i, t}-$ proxy for the leverage of company $i$ in year $t$ $* * *, * *, *$, significant at $1 \%, 5 \%$, and $10 \%$, respectively.

Source: Prepared by the author.

The model results, displayed in Table 4, show that both for the sample for informativeness and for the sample with comparable elements, the estimated coefficient of the interactive variable between adjusted net earnings and the dummy for $\mathrm{HA}\left(\mathrm{ANE}_{\mathrm{i}, \mathrm{t}}{ }^{*} \mathrm{DHA}_{\mathrm{i}, \mathrm{t}}\right)$ was negative and significant at $5 \%$. These results show that $\mathrm{HA}$ has a negative influence on book earnings informativeness.

According to the $\mathrm{H}_{2}$ test, we see that the results found are opposite to expectations and contrary to the theory referred to by DeMarzo and Duffie (1995). Thus, both the general sample and the sample of comparable elements reject the hypothesis $\mathrm{H}_{2}$.

The results obtained for the study samples concerning informativeness show that, in the Brazilian stock market, HA reduces disclosed book earnings informativeness. Thus, we may assume that the market is anticipating information on the book outcomes of companies that have HA. Considering the increased production of private information (predisclosure) for companies that adopt HA, which tend to be followed up by analysts on a closer basis (Panaretou et al., 2013), the market might be more likely to react with less surprise to accounting disclosure by these companies.

\subsection{Disclosure Analysis of Derivatives and Hedge Accounting}

Descriptive statistics of quantitative variables in the disclosure model is provided in Table 5.

Table 5 Descriptive statistics for the disclosure model

\begin{tabular}{ccccccc}
\hline Panel A - Sample for the disclosure model & & & & & \\
\hline Variables & Obs. & Mean & Median & Standard deviation & Min. & Max. \\
\hline DDI & 100 & 9.23 & 9 & 1.8415 & 5 & 12 \\
\hline SIZE & 100 & 16.602 & 16.4392 & 1.1992 & 14.0795 & 20.3342 \\
\hline LEV & 100 & 0.5897 & 0.6077 & 0.1513 & 0.1196 & 0.9245 \\
\hline LIQ & 100 & 0.7921 & 0.5135 & 1.3342 & 0 & 7.4737 \\
\hline
\end{tabular}

Note. $D D I_{i, t}$ - disclosure indicator of derivatives of company $i$ in year $t, S I Z E_{i, t}-$ proxy for size of company $i$ in year $t, L E V_{i, t}-$ proxy for leverage of company $i$ in year $t ;$ $L / Q_{i, t}$ - stock market liquidity of company $i$ in year $t$.

Source: Prepared by the author.

Descriptive analyses for the variable DDI show that companies had a mean score of 9.23, out of a maximum score of 12. This piece of data shows that some companies are not providing required items as for the use of derivatives.

Table 6 displays the results of regression for the disclosure model. 


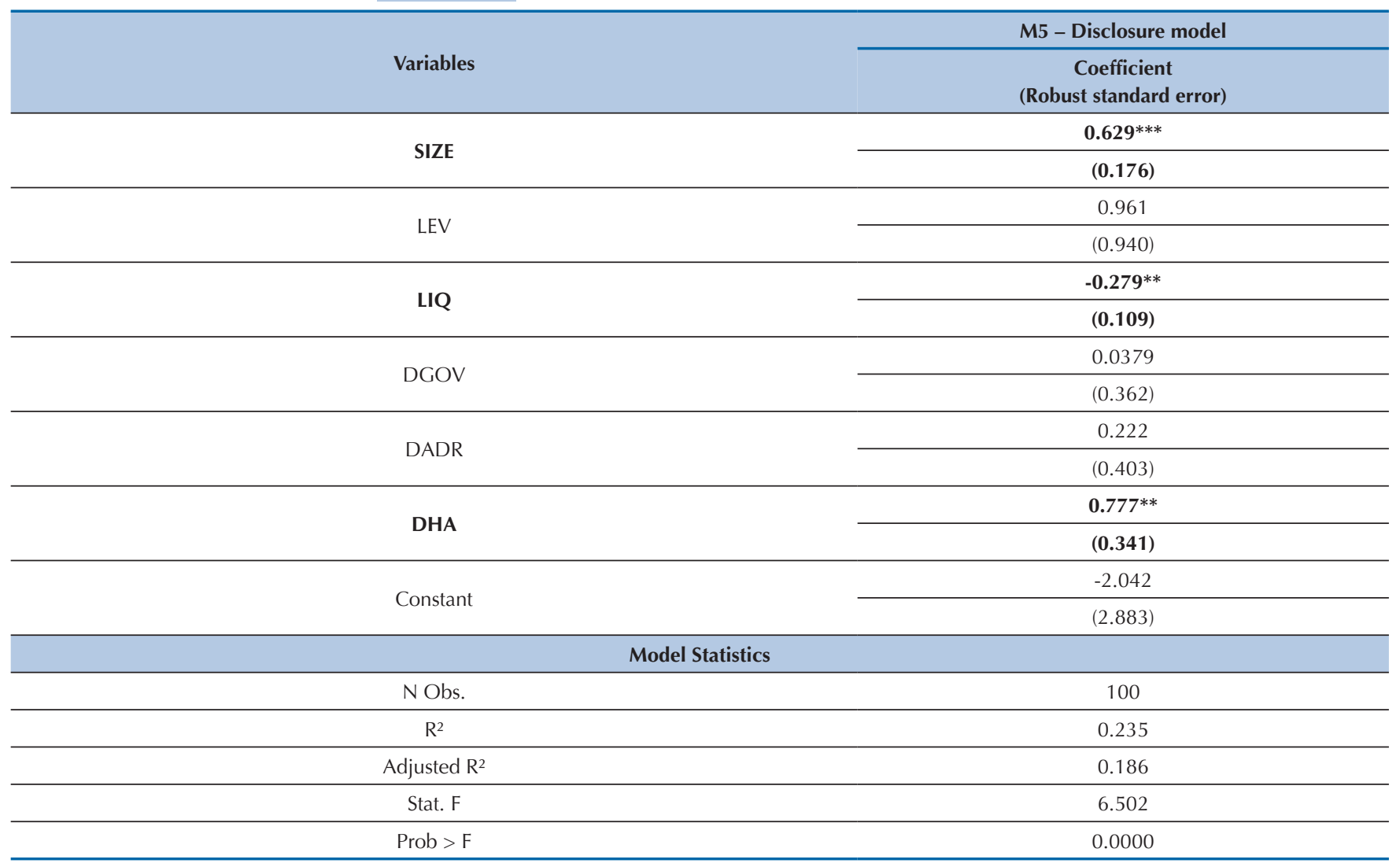

Note. $D D I_{i, t}$ - derivatives disclosure indicator of company $i$ in year $t, S I Z E_{-}$- proxy for size of company $i$ in year $t, L E V_{i,-}$ leverage of company $i$ in year $t, L I Q_{i t}-$ stock market liquidity of company $i$ in year $t, D G O V_{i, t}$-dummy variable that takes value 1 for companies adhering to one of the different listing segments Level 1 , Level 2 ,

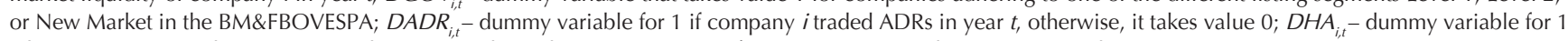
when company $i$ used HA in year $t$, otherwise, it takes value $0 ; * * *, * *$, , significant at $1 \%, 5 \%$, and $10 \%$, respectively.

Source: Prepared by the author.

We observe that, according to the variable SIZE, the estimated value of its coefficient was positive and significant at $1 \%$, indicating that the larger a company size, the higher the score obtained in DDI, resulting in greater adherence to compliance with the CPC 40(R1) and, as a consequence, exerting a positive influence on reduced information asymmetry, regarding the use of derivatives. This evidence is in line with the findings by Lanzana (2004) and Murcia and Santos (2009).

However, by analyzing the variable LIQ, we notice that the estimated value of its coefficient had a negative and significant sign at $5 \%$, indicating an inverse relation. Thus, it is understood that the higher stock market liquidity of a company, the lower the score assigned to the variable DDI, negatively impacting on compliance with the CPC 40(R1) and, by implication, having a negative impact on reducing information asymmetry as for the use of derivatives. This outcome is contrary to the expected by the disclosu- re theory and the findings by Lanzana (2004). Assessing the relation between disclosure and governance, Lanzana (2004) showed that companies whose shares have higher liquidity tend to have a higher disclosure level. Thus, it is possible to conjecture that the results found by Lanzana (2004) may not converge to the disclosure theory related to HA and compliance with the CPC 40(R1).

Nevertheless, it is seen, in Table 6, that the estimated value for the coefficient of the variable of interest in the model (DHA) to test $\mathrm{H}_{3}$ was positive and significant at $5 \%$. This result is consistent with the theory, indicating that HA has a positive influence on the disclosure level of derivatives, pointed out by the DDI. So, non-rejection of the hypothesis $\mathrm{H}_{3}$ becomes clear.

Notwithstanding, in order to determine the causal effect of HA on the disclosure level of derivatives, we resorted to the PSM method. The results are displayed in Table 7 .

Table 7 Results of the DHA logistic regression - PSM disclosure

\begin{tabular}{ccc}
\hline & & Dependent variable $=$ DHA \\
\cline { 2 - 3 } Cariables & $\begin{array}{c}\text { Coefficient } \\
\text { (Standard error) }\end{array}$ \\
\hline SIZE & 0.4564 \\
\cline { 2 - 3 } \\
\hline LEV
\end{tabular}




\begin{tabular}{|c|c|c|c|c|c|c|}
\hline & \multirow{2}{*}{\multicolumn{2}{|c|}{ LIQ }} & & \multicolumn{3}{|c|}{0.4038} \\
\hline & & & & & $(0.4196)$ & \\
\hline & \multirow{2}{*}{\multicolumn{2}{|c|}{ DGOV }} & & & -0.0959 & \\
\hline & & & & & $(0.5630)$ & \\
\hline & \multirow{2}{*}{\multicolumn{2}{|c|}{ DADR }} & & & 0.8111 & \\
\hline & & & & & $(0.5925)$ & \\
\hline & \multirow{2}{*}{\multicolumn{2}{|c|}{ Constant }} & & & $-8.8692^{*}$ & \\
\hline & & & & & (5.1173) & \\
\hline \multicolumn{7}{|c|}{ Model Statistics } \\
\hline \multicolumn{4}{|c|}{ N Obs. } & \multicolumn{3}{|c|}{100} \\
\hline \multicolumn{4}{|c|}{ Pseudo $R^{2}$} & \multicolumn{3}{|c|}{0.148} \\
\hline \multicolumn{4}{|c|}{ LR chi ${ }^{2}$} & \multicolumn{3}{|c|}{20.48} \\
\hline \multicolumn{4}{|c|}{ Prob $>\mathrm{chi}^{2}$} & \multicolumn{3}{|c|}{0.001} \\
\hline Variable & Sample & Processed & Control & Difference & Standard error & Statistics $t$ \\
\hline \multirow{2}{*}{ DDI } & Unmatched & 9.8750 & 8.6346 & 1.2404 & 0.3486 & 3.56 \\
\hline & ATT & 9.8750 & 8.9583 & 0.9167 & 0.5822 & 1.57 \\
\hline
\end{tabular}

Note. $D D I_{i, t}$ - derivatives disclosure indicator of company $i$ in year $t, S I Z E_{i, t}-$ proxy for size of company $i$ in year $t ; L E V_{i, t}-$ leverage of company $i$ in year $t, L I Q_{i, t}-$ stock market liquidity of company $i$ in year $t, D G O V_{i, t}$ - dummy variable for 1 for companies adhering to one of the different listing segments Level 1 , Level 2, or New Market in the BM\&FBOVESPA; $D A D R_{\text {- }}$ - dummy variable that takes value 1 if company $i$ traded ADRs in year $t$, otherwise, it takes value 0 ; $D H A$ - dummy variable for 1 when company $i$ used HA in year $t$, otherwise, it takes value $0 ; A T T$-average treatment effect on the treated; ***,**, , significant at $1 \%$, $5 \%$, and $10 \%$, respectively. Source: Prepared by the author.

According to Table 7, we notice a positive mean difference and statistically significant at 1.2404 in DDI when analyzing companies that adopted and did not adopt HA. However, when providing PSM, we still find a positive difference (0.9167), but not significant, considering statistics $t$ (1.57).

In this occasion, the results demonstrate that HA has a positive impact on adherence to compliance with the CPC 40(R1). One possible explanation for this may be the enforcement generated by meeting the criteria for formal designation in the hedge relation to qualify HA. So, $\mathrm{H}_{3}$ is not rejected.

\subsection{Analysis of Information Asymmetry and Hedge Accounting}

As highlighted in the previous section, the enforcement generated by meeting the criteria for designation of HA may be impacting the evidence found. So, the next analysis seeks to portray whether higher disclosure - related to companies that operated with HA - resulted in lower information asymmetry. To do this, the dispersion variable of analysts' average forecasts (DAFA) will be taken as a proxy for information asymmetry.

The descriptive statistics of quantitative variables in the model for information asymmetry is provided in Table 8.

Table 8

Descriptive statistics for the information asymmetry model

\begin{tabular}{|c|c|c|c|c|c|c|}
\hline Variables & Obs. & Mean & Median & Standard deviation & Min. & Max. \\
\hline DAFA & 66 & 0.8508 & 0.8354 & 0.1398 & 0.6405 & 1.0468 \\
\hline DDI & 66 & 9.1212 & 9 & 1.8104 & 5 & 12 \\
\hline SIZE & 66 & 16.7785 & 16.6961 & 1.1747 & 14.9086 & 19.4025 \\
\hline LEV & 66 & 0.5910 & 0.6085 & 0.1433 & 0.2966 & 0.8854 \\
\hline LIQ & 66 & 1.0325 & 0.5813 & 1.4862 & 0 & 6.5803 \\
\hline
\end{tabular}

Note. $D A F A_{i, t}$ - dispersion of analysts' average forecasts of company $i$ in year $t, D D I_{i, t}-$ derivatives disclosure indicator of company $i$ in year $t$; $S I Z E_{i, t}-$ proxy for size of company $i$ in year $t$; LEV - proxy for leverage of company $i$ in year $t$; LIQ - stock market liquidity of company $i$ in year $t$.

Source: Prepared by the author.

The results of regression for the information asymmetry model are displayed in Table 9. 
Table $9 \quad$ Results of regression for the information asymmetry model

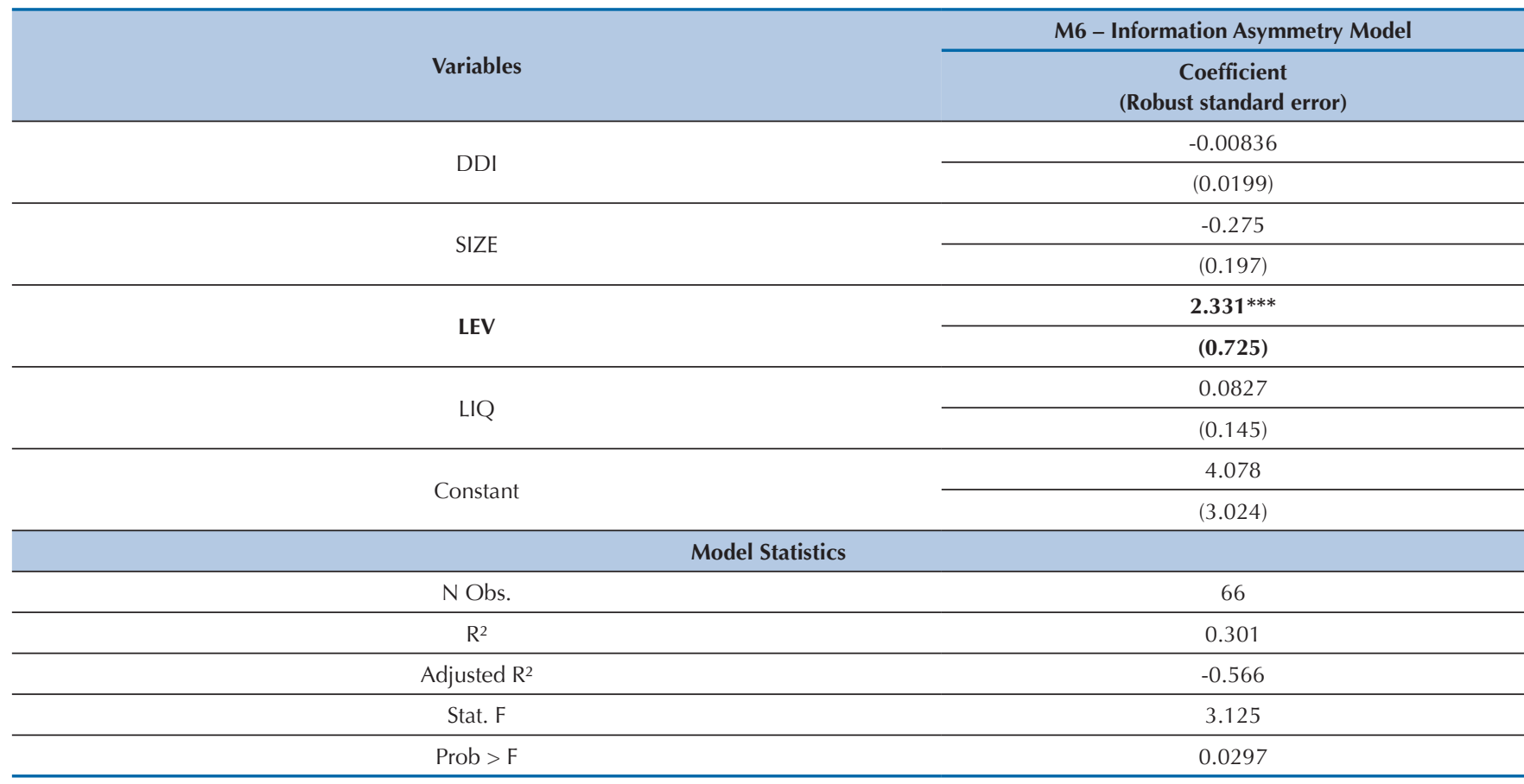

Note. $D D I_{i, t}$ - derivatives disclosure indicator of company $i$ in year $t, S I Z E_{i, t}-$ proxy for size of company $i$ in year $t ; L E V_{i, t}-$ leverage of company $i$ in year $t, L I Q_{i, t}-$ stock market liquidity of company $i$ in year $t .{ }^{* * *}, * *, *$, significant at $1 \%, 5 \%$, and $10 \%$, respectively.

Source: Prepared by the author.

Based on Table 9, we notice a statistically significant relation of the variable leverage (LEV), demonstrating that this is positively associated with the dispersion of analysts' forecasts. Regarding the variable of interest (DDI), although it has shown the expected sign, indicating that the disclosure level reduces the dispersion of analysts' average forecasts and, by analogy, information asymmetry, the variable was not statistically significant. The dummy variables of governance (DGOV) and ADRs (DADR) were omitted from the model due to collinearity issues with the other variables.

We also sought to investigate the causal effect of HA on information asymmetry. To do this, the PSM method was used. The results are displayed in Table 10.

Table 10 Results of the DHA regression logistics - PSM information asymmetry

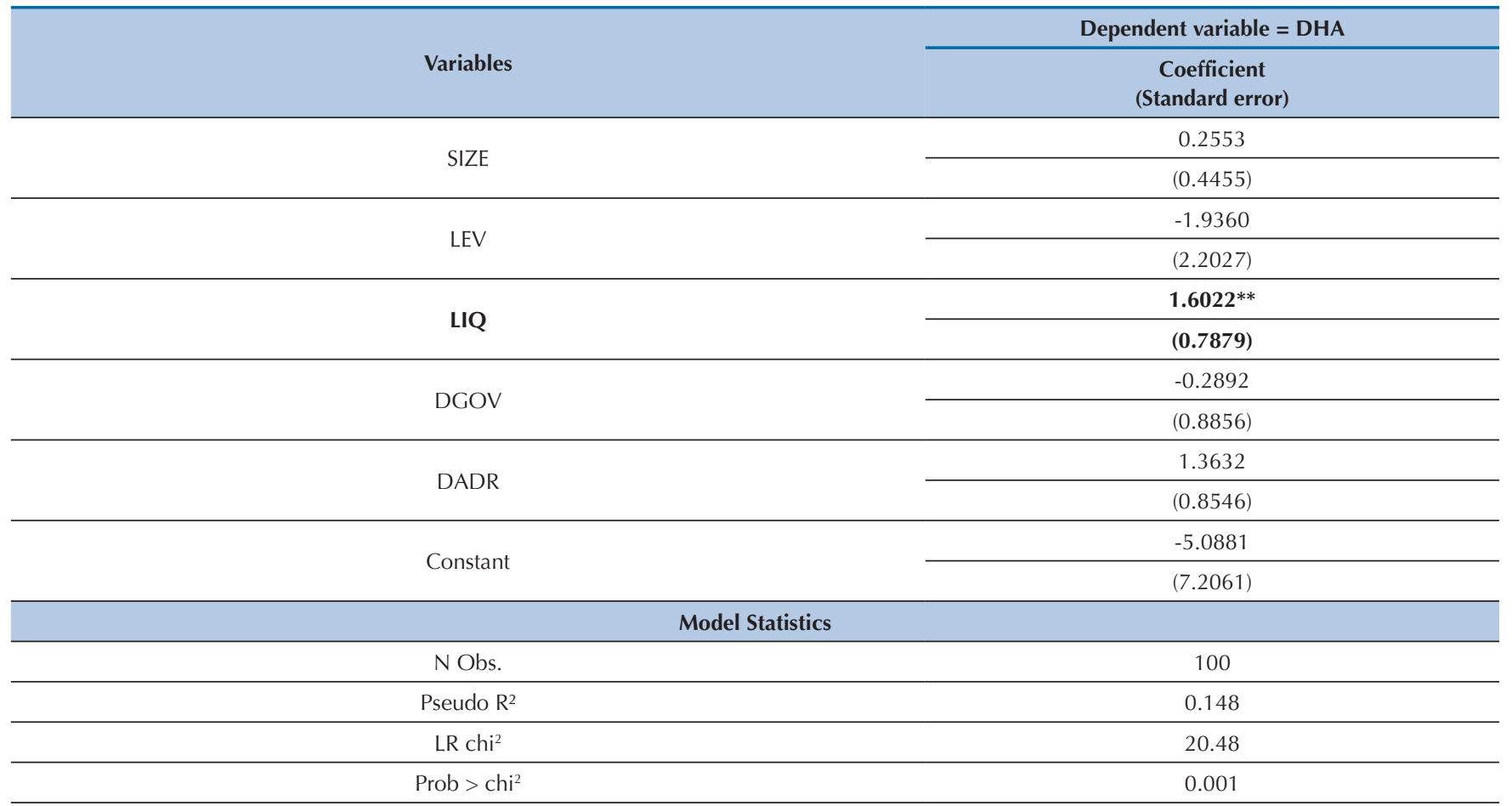


Table 10 Cont.

\begin{tabular}{cccccccc}
\hline Variable & Sample & Processed & Control & Difference & Standard error & Statistics t \\
\hline \multirow{2}{*}{ DAFA } & Unmatched & 0.8283 & 0.8663 & -0.0381 & 0.0349 & -1.09 \\
\cline { 2 - 8 } & ATT & 0.8283 & 0.9218 & -0.0935 & 0.0608 & -1.54 \\
\hline
\end{tabular}

Note. $D D I_{i, t}$ - derivatives disclosure indicator of company $i$ in year $t, S I Z E_{i, t}-$ proxy for size of company $i$ in year $t ; L E V_{i, t}-$ leverage of company $i$ in year $t, L I Q_{i, t}-$ stock market liquidity of company $i$ in year $t, A T T$ - average treatment effect on the treated. $* * *, * * *$, significant at $1 \%, 5 \%$, and $10 \%$, respectively.

Source: Prepared by the author.

The results displayed in Table 10 show a negative average difference, indicating that companies adopting HA had lower average dispersion than those that did not adopt it. However, for both samples, the result was not statistically significant.

\section{FINAL REMARKS}

This research aimed to investigate the effect of informational content of HA on quality of accounting information disclosed by non-financial companies listed on the BM\&FBOVESPA, as well as verify the influence of HA on the disclosure level of derivative financial instruments of non-financial companies listed on the BM\&FBOVESPA and, due to that, on information asymmetry.

Empirical evidence was obtained by means of the multivariate technique of multiple regression on panel data, based on: the sample data from 150 non-financial companies listed on the BM\&FBOVESPA, ranked by market value on December 30, 2013, from 2008 to 2013, for analyzing the quality of accounting information; the sample with data from 50 non-financial companies listed on the BM\&FBOVESPA, ranked by market value on December 30, 2013, for the years 2011 and 2012, for analyzing
Regarding the expected results for the model for information asymmetry, it is observed that $\beta_{1}$ showed the expected sign (Table 9), but it was not statistically significant, as well as ATT in PSM (Table 10). Thus, for a hypothesis test, there was a rejection to $\mathrm{H}_{4}$.

\section{Table 11 Results by hypotheses}

\begin{tabular}{cccc}
\hline Hypothesis & Expected sign & Sign found & Result \\
\hline $\mathrm{H}_{1}$ & + & Significant & Not rejected \\
\hline $\mathrm{H}_{2}$ & + & $\begin{array}{c}- \\
\text { Significant }\end{array}$ & Rejected \\
\hline $\mathrm{H}_{3}$ & + & + & Not rejected \\
\hline $\mathrm{H}_{4}$ & - & Significant & Rejected \\
\hline
\end{tabular}

Source: Prepared by the author.

Evidence found - for the influence of HA on quality of accounting information - allows conjecturing that the Brazilian market may be anticipating information on earnings reported by companies or also seeing HA as a earnings management mechanism, rather than risk management. This assumption may be corroborated by the recent cases of large companies that adopted this modality and its consequent results, something which the disclosure level; and the sample with data from 33 non-financial companies listed on the BM\&FBOVESPA, taken from the sample for disclosure, for the years 2011 and 2012, for analyzing information asymmetry.

In order to achieve the proposed objective, we used econometric models of: information relevance, adapted from the model by Ohlson (1995); book earnings informativeness, adapted from the model by Easton and Harris (1991); disclosure, according to Lanzana (2004), Alencar (2005), and Murcia and Santos (2009) for determining the variables of the model concerned; information asymmetry, according to Dadalt et al. (2002). The PSM method was also used to investigate the impact of HA, in the causal relation, on disclosure and information asymmetry.

Table 11 presents a summary of the results, according to the research hypotheses. put the theme HA in vogue in the national scene and led it to be recurrently addressed by specialized media.

Regarding the evidence found for the influence of HA on the disclosure of derivatives, we may claim that HA has a positive influence on reducing information asymmetry, as for the use of derivatives. The need to meet the criteria for formal designation of the hedging relation to qualify $\mathrm{HA}$ and the need to disclose greater 
volume of information may justify and explain the evidence found.

Concerning the evidence found for information asymmetry, the relatively small number of companies analyzed may represent a limitation of this research, given that the resulting low variability may reflect on not significant model coefficients.

The conclusions pointed out in this study are subject to the companies analyzed, in their respective research samples. Thus, extrapolation of the results may lead to uncertain and even untruthful conclusions, something which allows us to suggest further studies with more explanation on the subject, above all concerning the reassessment of the Brazilian market sensitivity as for the adoption of HA.

Having in mind that the theme HA is still a vast field for studies in the Brazilian literature, we suggest as a future research subject the informational content of hedge from the perspective of other metrics for the quality of accounting information, such as timing, conservatism, and earnings management, or even an expanded study addressing the influence of HA on disclosure, given the incipience of studies addressing the theme.

\section{References}

Alencar, R. C. (2005). Custo do capital próprio e nível de disclosure nas empresas brasileiras. Brazilian Business Review, 2(1), 1-12.

Almeida, J. E. F. (2010). Qualidade da informação contábil em ambientes. competitivos (Doctoral Thesis). Universidade de São Paulo, São Paulo.

Amaral, C. A. L. V. (2003): Derivativos: o que são e à evolução quanto ao aspecto contábil. Revista Contabilidade \& Finanças, 14(32), 71-80.

Ball, R., \& Brown, P. (1968). An empirical evaluation of accounting income numbers. Journal of Accounting Research, 6(2), 159-178.

Barth, M. E., Beaver, W. H., \& Landsman, W. R. (2001). The relevance of the value relevance literature for financial accounting standard setting: another view. Journal of Accounting and Economics, 31(1), 77-104.

Beaver, W. H. (1968). The information content of annual earnings announcements. Journal of Accounting Research, 67-92.

Beaver, W. H., Clarke, R., \& Wright, W. F. (1979). The association between unsystematic security returns and the magnitude of earnings forecast errors. Journal of accounting research, 316-340.

Brugni, T. V., Sarlo Neto, A., Bastianello, R. F., \& Paris, P. K. S. (2012). Influência de dividendos sobre a informatividade dos lucros: evidências empíricas na BM\&FBOVESPA. Revista Universo Contábil, 8(3), 82-99.

Bushman, R. M., \& Smith, A. J. (2001). Financial accounting information and corporate governance. Journal of Accounting and Economics, 32(1-3), 237-333. Retrieved from http://doi.org/10.1016/S01654101(01)00027-1

Chen, W., Tan, H. T., \& Wang, E. Y. (2013). Fair value accounting and managers' hedging decisions. Journal of Accounting Research, 51(1), 67-103. Retrieved from http://doi.org/10.1111/j.1475679X.2012.00468.x

Collins, D. W., \& Kothari, S. P. (1989). An analysis of intertemporal and cross-sectional determinants of earnings response coefficients. Journal of Accounting and Economics, 11(2-3), 143-181. Retrieved from http://doi.org/10.1016/0165-4101(89)90004-9

CPC 38 (2009). Pronunciamento Técnico. CPC 38 - Instrumentos Financeiros: Reconbecimento e Mensuração.

Dadalt, P., Gay, G. D., \& Nam, J. (2002). Asymmetric information and corporate derivatives use. Journal of Futures Markets, 22(3), 241-267.

Darós, L. L., \& Borba, J. A. (2005). Evidenciação de instrumentos. financeiros derivativos nas demonstrações contábeis: uma análise das empresas brasileiras. Revista Contabilidade \& Finanças, 16(39), 68-80.

Dechow, P., Ge, W., \& Schrand, C. (2010). Understanding earnings quality: $A$ review of the proxies, their determinants and their consequences. Journal of Accounting and Economics, 50(2-3), 344-401. Retrieved from http://doi.org/10.1016/j.jacceco.2010.09.001

DeMarzo, P. M., \& Duffie, D. (1995). Corporate incentives for hedging and hedge accounting. Review of Financial Studies, 8(3), 743-771. Retrieved from http://doi.org/10.1093/rfs/8.3.743

Dhaliwal, D. S., Lee, K. J., \& Fargher, N. L. (1991). The association between unexpected earnings and abnormal security returns in the presence of financial leverage. Contemporary Accounting Research, 8(1), 20-41. Retrieved from http://doi.org/10.1111/j.1911-3846.1991 tb00832.x

Easton, P. D., \& Harris, T. S. (1991). Earnings as an explanatory variable for returns. Journal of Accounting Research, 19-36.
Francis, J., Olsson, P., \& Schipper, K. (2006). Earnings Quality. Foundations and Trends in Accounting 1(4), 259-340. Retrieved from http://dx.doi.org/10.1561/1400000004

Freeman, R. N. (1987). The association between accounting earnings and security returns for large and small firms. Journal of Accounting and Economics, 9(2), 195-228. Retrieved from http://doi. org/10.1016/0165-4101(87)90005-X

Healy, P. M., \& Palepu, K. G. (2001). Information asymmetry, corporate disclosure, and the capital markets: a review of the empirical disclosure literature. Journal of Accounting and Economics, 31(1), 405-440.

Hughen, L. (2010). When do accounting earnings matter more than economic earnings? Evidence from hedge accounting restatements. Journal of Business Finance \& Accounting, 37(9-10), 1027-1056. Retrieved from http://doi.org/10.1111/j.1468-5957.2010.02216.x

Jensen, M. C., \& Meckling, W. H. (1976). Theory of the firm: Managerial behavior, agency costs and ownership structure. Journal of Financial Economics, 3(4), 305-360. Retrieved from http://doi. org/10.1016/0304-405X(76)90026-X

La Porta, R., Lopez-de-Silanes, F., Shleifer, A., \& Vishny, R. (2000). Investor protection and corporate governance. Journal of financial economics, 58(1), 3-27.

Lanzana, A. P. (2004). Relação entre disclosure e governança corporativa das empresas brasileiras (Master's Degree). Universidade de São Paulo, São Paulo. Retrieved from http://www.teses.usp.br/teses/ disponiveis/12/12139/tde-11022005-094807/pt-br.php

Lin, J. B., Pantzalis, C., \& Park, J. C. (2010). Corporate hedging policy and equity mispricing. Financial Review; 45(3), 803-824. Retrieved from http://doi.org/10.1111/j:1540-6288.2010.00272.x

Lọes, A. B. (2002). Informação contábil e o mercado de capitais. São Paulo, SP: Thomson.

Lopes, A. B. (2009). The relation between firm-specific corporate governance, cross-listing and the informativeriess of accounting numbers in Brazil (Doctoral Thesis). The University of Manchester, Manchester.

Lopes, A. B., Galdi, F. C., \& Lima, I. S. (2009). Manual de contabilidade e tributação de instrumentos financeiros e derivativos (IAS 39, IAS 32, IFRS 7, CPC 14, minutas do CPC 38, 39 e 40, normas da CVM, do Bacen e da Receita Federal do Brasil). São Paulo, SP: Atlas.

Lopes, A. B., \& Martins, E. (2012): Teoria da contabilidade: uma nova abordagem (3. reimpr.). São Paulo, SP: Atlas.

Modigliani, F., \& Miller, M. H. (1958). The cost of capital, corporation finance and the theory of investment. The American Economic Review, 48(3), 261-297.

Murcia, F. D. R., \& Santos, A. (2009). Fatores determinantes do nível de disclosure voluntário das companhias abertas no Brasil. Revista de Educação e Pesquisa em Contabilidade, 3(2), 72-95.

Ohlson, J. A. (1995). Earnings, book values, and dividends in equity valuation. Contemporary Accounting Research, 11(2), 661-687. Retrieved from http://doi.org/10.1111/j.1911-3846.1995.tb00461.x

Panaretou, A., Shackleton, M. B., \& Taylor, P. A. (2013). Corporate risk management and hedge accounting. Contemporary Accounting Research, 30(1), 116-139. Retrieved from http://doi.org/10.1111/ j.1911-3846.2011.01143.x 
Pirchegger, B. (2006). Hedge accounting incentives for cash flow hedges of forecasted transactions. European Accounting Review, 15(1), 115-135. Retrieved from http://doi.org/10:1080/09638180500510509

Plantin, G., Sapra, H., \& Shin, H. S. (2008). Marking-to-market: Panacea or Pandoras box? Journal of Accounting Research, 46(2), 435-460. Retrieved from http://doi.org/10.1111/j.1475-679X.2008.00281.x

Rosenbaum, P. R., \& Rubin, D. B.. (1983). The central role of the propensity score in observational studies for causal effects. Biometrika, 70(1), 4155. Retrieved from http://doi.org/10.1093/biomet/70.1.41

Sarlo Neto, A., Bassi, B. R., \& Almeida, A. A. (2011). Um estudo sobre a informatividade dos lucros contábeis na América Latina. Revista de Contabilidade e Organizações, 5(12), 4-25.

Sarlo Neto, A., Galdi, F. C., \& Dalmácio, F. Z. (2009). Uma pesquisa sobre o perfil das ações brasileiras que reagem à publicação dos resultados contábeis. Revista de Contabilidade e Organizações, 3(6), 22-40.

Sarlo Neto, A., Lopes, A. B., \& Dalmácio, F. Z. (2010). A influência da estrutura de propriedade sobre a informatividade dos lucros contábeis divulgados pelas empresas negociadas na Bovespa. Revista Base (Administracão E Contabilidade) Da UNISINOS, 7(4), 301-314.

Scott, W. R. (2011). Financial accounting theory. Toronto, Canada: Pearson Canada.

Silva, F. C. (2014). Hedge accounting no Brasil (Doctoral Thesis).
Universidade de São Paulo, São Paulo

Stulz, R. M. (1984). Optimal hedging policies. Journal of Financial and Quantitative Analysis, 19(02), 127-140. Retrieved from http://doi. org/10.2307/2330894

Vafeas, N. (2000). Board structure and the informativeness of earnings Journal of Accounting and Public Policy, 19(2), 139-160. Retrieved from http://doi.org/10.1016/S0278-4254(00)00006-5

Viri, N. (2013,09 de agosto). Petrobras sai de prejuízo para lucro de R\$ 6,2 bilhões no 2o trimestre. Valor Econômico. Retrieved from http:// www.valor.com.br/empresas/3228478/petrobras-sai-de-prejuizopara-lucro-de-r-62-bilhoes-no-2

Wang, D. (2006). Founding family ownership and earnings quality. Journal of Accounting Research, 44(3), 619-656.

Watts, R. L., \& Zimmerman, J. L. (1986). Positive accounting theory. Retrieved from http://papers.ssrn.com/sol3/papers.cfm?abstract_ id $=928677$

Yokoyama, K. Y., Baioco, V. G., Rodrigues Sobrinho, W. B., \& Neto, A. S. (2015). A influência do tamanho da empresa na informação contábil: evidências em empresas large caps e small caps listadas na BM\&FBovespa. Revista de.Educação e Pesquisa em Contabilidade (REPeC), 9(3). Retrieved from http://doi.org/10.17524/repec v9i3.1275

\section{Correspondence Address:}

\section{Silas Adolfo Potin}

Universidade Federal do Espírito Santo, Centro de Ciências Jurídicas e Econômicas

Av. Fernando Ferrari, 514 - CEP: 29075-910

Goiabeiras - Vitória - ES

Email: silas.potin@ufes.b 